\title{
Melt Grafting of Citraconic Acid onto an Ethylene-Propylene-Diene Terpolymer (EPDM) \\ -Effect of Reaction Conditions and Initiator Type on the Melt Grafting of Citraconic Acid onto EPDM-
}

\author{
Jung-Soo Kim, Jong-Woo Bae, Jin-Hyok Lee, Gu-Ni Kim, Sang-Taek Oh, Young-Hee Lee ,Han-Do Kim*,† \\ Industrial Materials Fusion Technology Center, Korea Institute of Footwear and Leather Technology, Busan \\ 614-100, Korea \\ *Department of Organic Material Science and Engineering, Pusan National University, Busan 609-735, Korea
}

(Received December 17, 2012, Revised December 27, 2012, Accepted January 3, 2013)

\author{
EPDM고무와 씨트라코닉산의 melt grafting \\ - 반응조건과 개시제에 따른 영향 연구 - \\ 김정수 · 배종우 · 이진혁 · 오상택 · 김구니 · 이영희 · 김한도*† \\ 한국신발피혁연구소 산업소재융합기술센터, \\ *부산대학교 유기소재공학과 \\ 접수일(2012년 12월 17일), 수정일(2012년 12월 27일), 게재확정일(2013년 1월 3일)
}

\begin{abstract}
Melt grafting of citraconic acid (CCA) onto an ethylene-propylene-diene terpolymer (EPDM) with various peroxide initiators was performed using a Haake Rheocorder. Finding the optimum running condition and concentration is critical for effective grafting and performance of grafted material. Therefore, this study focused on the effects of mixing (reaction) condition and monomer/initiator dosages on the grafting degree, grafting efficiency and crosslinking degree (gel content), melt flow index and mechanical properties of CCA-g-EPDM. As the grafting degree/crosslinking degrees increased, the tensile strength increased significantly, but elongation at break and melt flow index decreased. The initiator 2,5-dimethyl-2,5-di(tert-butyl peroxy)-hexane (T-101) appeared to meet for the best grafting $(2.31 \%)$. The grafting degree increased markedly with increasing monomer CCA/initiator T-101 contents. The grafting degree also increased with increasing mixing temperature/time, and then leveled off or decreased/increased a little. The optimum monomer/initiator dosages and reaction temperature/time were found to be about $5 / 0.05 \mathrm{wt} \%$ and $180{ }^{\circ} \mathrm{C} / 15 \mathrm{~min}$, respectively.

요 약 : Haake Rheocorder로 각종 과산화물 개시제를 사용하여 ethylene-propylene-diene terpolymer (EPDM) 에 단량체 citraconic acid (CCA)을 용융 그라프트 중합을 하여 그라프트 중합물 CCA-g-EPDM을 얻었으며, 이 때 효율적인 그라프트 정도와 우수한 성능을 지닌 그라프트 중합물을 얻기 위해서 최적의 반응조건과 최적의 단량체/개 시제 농도를 찾는 것은 매우 중요하다. 따라서 본 연구에서는 반응조건과 단량체 및 개시제 함량이 CCA-g-EPDM의 그라프트 정도, 그라프트 효율, 가교정도 (겔화도), 용융흐름지수(MI) 및 기계적 물성 등에 미치는 영향에 초점을 맞추었다. 그라프트 정도와 가교도가 증가함에 따라서 인장강도는 상당히 증가한 반면, 파괴신도 및 $\mathrm{MI}$ 는 감소하였다. 개시제 중에서 2,5-dimethyl-2,5-di(tert-butyl peroxy)-hexane (T-101)가 가장 우수한 그라프트 정도 (2.31 $\%$ )를 나타내었으며, CCA와 T-101의 함량이 증가함에 따라 그라프트 정도가 크게 증가하였다. 그리고 그라프트 정도는 반응(혼합)온도 및 반응시간이 증가함에 따라 역시 증가하다가 어느 온도/시간 이상에서는 안정화 혹은 약간 감소하는 경향을 나타내었다. 이러한 영향으로 결과로부터 최적의 단량체/개시제 농도는 $5 / 0.05 \mathrm{wt} \%$ 이었으며, 최적 의 반응온도/시간은 $180{ }^{\circ} \mathrm{C} / 15$ 분인 것을 알 수 있었다.
\end{abstract}

Keywords : melt grafting, citraconic acid, ethylene-propylene-diene terpolymer (EPDM), initiator

\section{Introduction}

${ }^{\dagger}$ Corresponding Author. E-mail: kimhd@pusan.ac.kr

Modification of conventional polymers by grafting and graft-copolymerization techniques has received much academic 
and practical interest. Among all possible chemical modification methods, free-radical grafting is probably the oldest, widely practiced and the most inexpensive one. Further advantages are gained with the use of batch mixers or screw extruders as chemical reactors, which allow the free-radical grafting reaction to occur without solvents. In principle, graft co-polymerization is an attractive method to impart a variety of functional groups to a polymer. ${ }^{1}$ It is essential to modify the properties of a polymer according to tailor-made specifications designed for target applications. Therefore, the modified polymers through grafting have a bright future and their development is practically boundless.

One of the most common monomers in the polymer modification is maleic anhydride (MA) and its isostructural analogues. MA and its isostructural analogues (maleic, fumaric, citraconic and itaconic acids and their derivatives) as polyfunctional monomers are being widely used in the synthesis of reactive macromolecules to prepare high performance engineering materials. ${ }^{2}$ In the last decade, grafting of MA onto various thermoplastic polymers (predominantly polyolefins) by using reactive extrude systems have been significantly developed. Fenouillot et al. $^{3}$ described the fundamental aspect of the reactive processing of thermoplastic polymers, including polymer grafting and/or functionalization using MA and vinylsilanes.

Bhattacharya and Misra ${ }^{1}$ have documented graft copolymerization reactions initiated by chemical treatment, photo-irradiation, high-energy radiation techniques, etc. as a versatile means to modify polymers. According to authors, there are several means to modify polymer properties such as blending, grafting, and curing. Among these methods of modification of polymers, grafting and graft copolymerization are one of the most promising methods. Rzayev $^{2}$ has reported different methods of grafting, including reactive extrusion systems, grafting and graft co-polymerization of synthetic and natural polymers with $\mathrm{MA}$ and its isostructural analogues.

Dimitrova et al. $^{4}$ has reported the melt free radical grafting of an oxazoline compound having basic reactive group onto
HDPE. There are a number of commercially available polymers containing acid reactive groups, ${ }^{5}$ such as MA-grafted onto ethylene-propylene-diene terpolymer EPDM (Du Pont), SEBS(Shell), PP(Himont) etc. Peroxide-initiated melt grafting of maleic anhydride (MAH) onto a EPDM of high ethylene content (74 wt\%) was performed using a Brabender Plasticoder. ${ }^{6}$ They found that both grafting and crosslinking reactions were mostly influenced by the dosage of the MAH and peroxide (2,5 - dimethyl-2,5di-( $t$-butylperoxy)hexane), respectively. The targeted relative high MAH grafting at low gel content was reached at low concentrations of both $\mathrm{MAH}(<5 \mathrm{wt} \%)$ and peroxide $(<0.2 \mathrm{wt} \%)$. Pesetskii et al. ${ }^{7-10}$ has reported the itaconic acid grafting on LDPE and itaconic acid/glycidyl methacrylate grafting on PP. However, research work related to citraconic acid (CCA)-graft-EPDM is rarely available in the open literature. The objective of this study is to find the optimum condition which result in a easy processible/highly performance grafted rubber(CCA-g-EPDM) with adequate crosslinking degree (gel content).

In this context, this study focused on the effects of the type of initiator, peroxide initiator and monomer CCA concentrations, mixing(reaction) conditions on the grafting degree, grafting efficiency and crosslinking degree (gel content) of CCA-g-EPDM. The relationship between grafting and melt flow index/mechanical properties of CCA-g-EPDM was also investigated.

\section{Experimental}

\section{Materials}

EPDM (contents of ethylene, propylene and ethylidenenorbornen: 70, 25.5 and $4.5 \mathrm{wt} \%$, respectively, KUMHO POLYCHEM, Korea), citraconic acid(CCA, Aldrich Chemical, Milwaukee, WI), dicumyl peroxide(Perkadox BC-FF, Akzo Nobel Co. Ltd, USA), 2,5-Bis(tert-butylperoxy)-2,5-dimethyl hexane(Trigonox 101, Akzo Nobel Co. Ltd, USA), Bis(tert-butylperoxy-isopropyl)-benzene(Perkadox 14S, Akzo Nobel Co. Ltd,

Table 1 sample code, grafting components, contents and properties of pristine EPDM and CCA-graft-EPDM samples

\begin{tabular}{|c|c|c|c|c|c|c|c|c|c|c|c|}
\hline \multirow[b]{2}{*}{ Sample code } & \multirow{2}{*}{$\begin{array}{l}\text { Grafting } \\
\text { EPDM }\end{array}$} & \multicolumn{2}{|c|}{ components/contents } & \multicolumn{8}{|c|}{ Properties } \\
\hline & & $\begin{array}{c}\text { Monomer } \\
\text { CCA } \\
(\mathrm{wt} \%)\end{array}$ & $\begin{array}{l}\text { Initiator } \\
\left(w t^{0} \%\right)\end{array}$ & $\begin{array}{c}\text { MFI } \\
(\mathrm{g} / 10 \mathrm{~min})\end{array}$ & $\begin{array}{l}\text { Hardness } \\
\text { (shore A) }\end{array}$ & $\begin{array}{r}\text { Specific } \\
\text { gravity }\end{array}$ & $\begin{array}{c}\text { Tensile } \\
\text { strength } \\
(\mathrm{MPa})\end{array}$ & $\begin{array}{c}\text { Elongation } \\
\text { at break } \\
(\%)\end{array}$ & $\begin{array}{c}\text { Modulus } \\
\text { at } 100 \% \\
(\mathrm{MPa})\end{array}$ & $\begin{array}{c}\text { Modulus } \\
\text { at } 300 \% \\
(\mathrm{MPa})\end{array}$ & $\begin{array}{c}\text { Tear strength } \\
(\mathrm{kN} / \mathrm{m})\end{array}$ \\
\hline Pristine EPDM & 100 & & & 12 & $46-47$ & 0.86 & 1.96 & 810 & 0.78 & 0.98 & 19.6 \\
\hline CCA-g-EPDM-D & 100 & 5 & $\operatorname{DCP}(0.05)$ & 12 & $59-60$ & 0.87 & 4.31 & 1180 & 1.27 & 1.67 & 26.5 \\
\hline CCA-g-EPDM-T & 100 & 5 & T101-1(0.05) & 9 & $56-57$ & 0.87 & 5.88 & 990 & 1.18 & 1.57 & 22.6 \\
\hline CCA-g-EPDM-P & 100 & 5 & P-14(0.05) & 10 & $59-60$ & 0.87 & 5.29 & 1095 & 1.27 & 1.57 & 23.5 \\
\hline
\end{tabular}

* $190{ }^{\circ} \mathrm{C}, 2.16 \mathrm{~kg}$, 


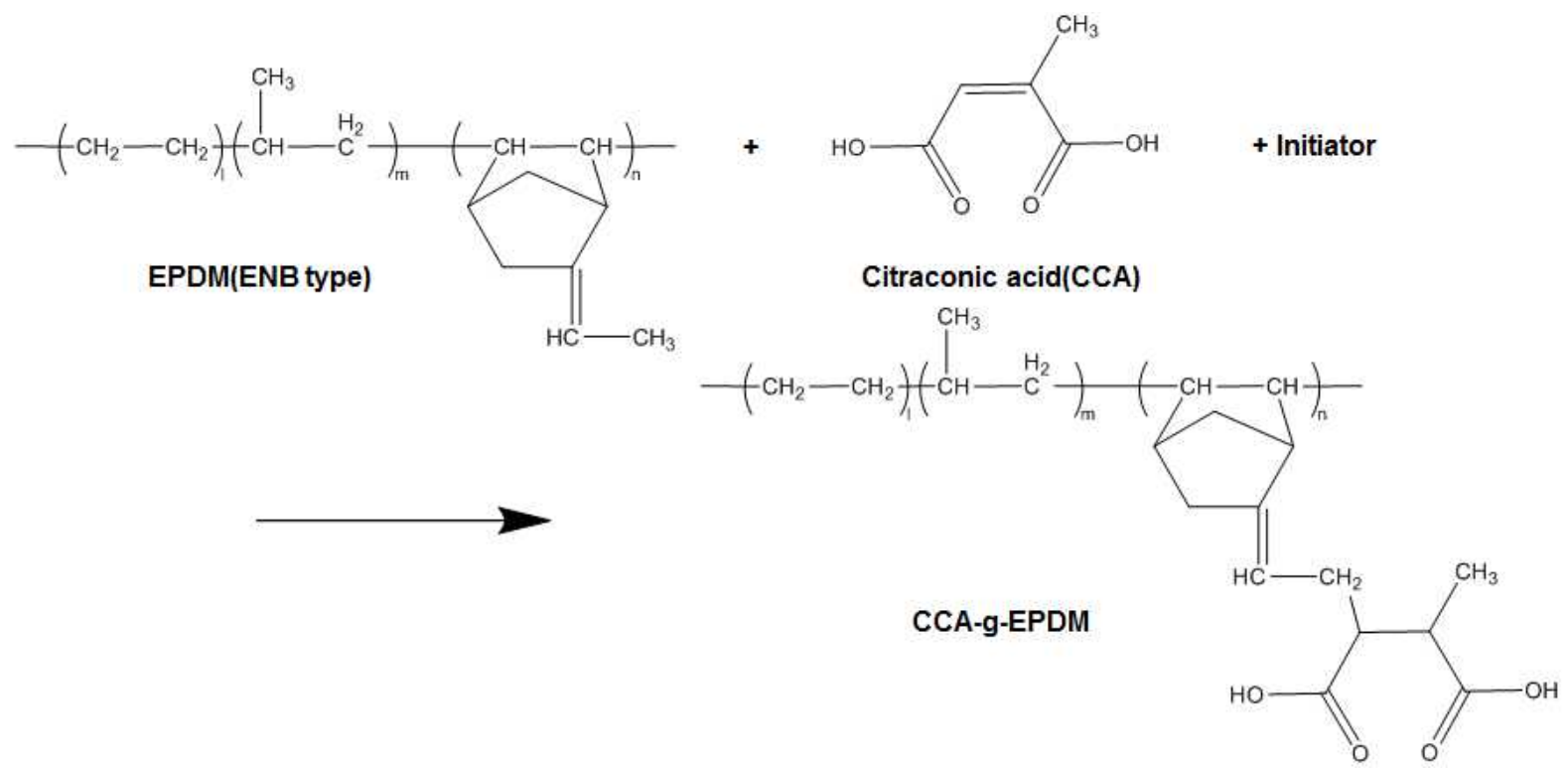

Scheme 1. Melt grafting reaction of citraconic acid (CCA) onto an ethylene-propylene-diene terpolymer (EPDM).

USA), xylene (Junsei Chemical Co., Ltd, Japan), acetone (Junsei Chemical Co., Ltd, Japan) and ethanol(Junsei Chemical Co., Ltd, Japan) were used without further purification.

\section{Melt grafting}

Citraconated EPDM (CCA-g-EPDM) was prepared from citraconic acid (CCA)/EPDM/peroxide initiator(DCP, T-101 and P-14) using a melt grafting technique with a Haake Rheocorder (Rheocord 9000, Haake Co., Germany) at 50rpm and $160{ }^{\circ} \mathrm{C}$ for 15 min. Sheet samples (thickness: $2 \mathrm{~mm}$ ) of pristine EPDM and CAA-g-EPDM were prepared by milling using an open mill (Yasuda Seiki Co., Model 191-TM, 6") at 160-170 ${ }^{\circ} \mathrm{C}$, followed by compression- molding at $180{ }^{\circ} \mathrm{C}$ for $10 \mathrm{~min}$.

The sample code and grafting components/contents of the pristine EPDM and CCA-graft-EPDM samples prepared in this study are given in Table 1. Melt grafting reaction of citraconic acid (CCA) onto an EPDM is presented in Scheme 1.

\section{Characterization}

Attenuated total reflectance (ATR)-Fourier transform infrared (FTIR 6200, Jasco, Japan) spectroscopy was used to confirm the chemical components of the pristine EPDM, CCA and CCAg-EPDM. For each sample, 32 scans at a $4 \mathrm{~cm}^{-1}$ resolution were collected in transmittance mode and recorded in the $2000-600 \mathrm{~cm}^{-1}$ range.
The grafting efficiency i.e. the ratio of the grafted CCA to its total quantity added to the EPDM, was accepted as the parameter describing the course of the grafting process. Such efficiency was determined, as in other studies, on film samples of thickness between 40 and 60 micrometer. It is based on the analysis of the monomer CCA added to the initial EPDM and that in CCA-g-EPDM, extracted in ethanol at $70{ }^{\circ} \mathrm{C}$ for $48 \mathrm{~h}$, or in acetone at $40{ }^{\circ} \mathrm{C}$ for $48 \mathrm{~h}$. Grafting degree (\% grafting) and graft efficiency (\%) of CCA-g-EPDM were determined by the following equations:

Grafting degree $=\left(\mathrm{W}_{\mathrm{g}}-\mathrm{W}_{\mathrm{o}}\right) / \mathrm{W}_{\mathrm{o}} \times 100$

Grafting efficiency $=\left(\mathrm{W}_{\mathrm{g}}-\mathrm{W}_{\mathrm{o}}\right) / \mathrm{W}_{\mathrm{CCA}} \times 100$

where the dry weights of CCA-g-EPDM extracted in acetone at $40{ }^{\circ} \mathrm{C}$ for $48 \mathrm{~h}$, pristine EPDM and added CCA are $\mathrm{W}_{\mathrm{g}}, \mathrm{W}_{\mathrm{o}}$ and $\mathrm{W}_{\mathrm{CCA}}$, respectively. The weight of grafted CCA is $\mathrm{W}_{\mathrm{g}}-\mathrm{W}_{\mathrm{o}}$.

Gel content (crosslinking degree) of the grafted EPDM was determined by soxhlet extraction in boiling xylene for $24 \mathrm{~h}$. The solution was filtered and the insoluble fraction has been dried in vacuum at $70{ }^{\circ} \mathrm{C}$ for $48 \mathrm{~h}$ prior to weighing. The gel content was defined as the weight $\%$ of the insoluble part of EPDM-g-CCA. Gel content (crosslinking degree, wt $\%$ ) was determined by the following equations:

Gel content (crosslinking degree, $\mathrm{wt} \%)=\mathrm{W}_{\text {insoluble }} / \mathrm{W}_{\mathrm{g}} \times 100$ 
Where the $\mathrm{W}_{\text {insoluble }}$ is the dry weight of insoluble EPDMg-CCA after extraction in boiling xylene for $24 \mathrm{~h}$ and the $\mathrm{Wg}$ is the dry weight of EPDM-g-CCA extracted in acetone at 40 ${ }^{\circ} \mathrm{C}$ for $48 \mathrm{~h}$

The melt flow index (MFI) measurement of the samples was carried out on a Melt Indexer CS127-604(CSI Ltd., U.S.A.) according to the ISO 1133:1999 standard, where the test temperature was set to $190{ }^{\circ} \mathrm{C}$ and the nominal load was $2.16 \mathrm{~kg}$. The tensile properties were measured according to the ASTM 638 specifications using a Universal Testing Machine (UTM Model 3345, Instron, U. S. A.). The values quoted are the average of five measurements. The hardness was measured using a shore A durometer (Asker, Kobunshi Co. Ltd, Japan) according to ASTM D-2240. The tear strength was measured using the Instron UTM 3345 using a $90^{\circ}$ nick cut-crescent sample according to ASTM 624-86. The density was measured at $23{ }^{\circ} \mathrm{C}$ using a $\mathrm{CCl}_{4}-\mathrm{n}$-heptane density gradient column method.

\section{Results and Discussion}

\section{Effect of mixing (reaction) conditions on the grafting and crosslinking}

From the results of effects of initiator type and dosages of initiator and monomer on the grafting and crosslinking, which is described later, the obtained optimum initiator [2,5-Dimethyl2,5-di(tert-butyl peroxy)-hexane(T-101)] content (0.05 wt\%) and monomer CCA content ( $5 \mathrm{wt} \%$ ) were fixed to investigate the effect of mixing(reaction) conditions on the grafting and crosslinking. Figure 1(a) shows the effect of reacting temperature on the grafting and crosslinking at a fixed reaction time (15 min). It was found that no reaction could occur at below $120{ }^{\circ} \mathrm{C}$. The grafting degree and grafting efficiency increased sharply with increasing reaction temperature up to about $180{ }^{\circ} \mathrm{C}$, and then decreased a little. The crosslinking degree increased markedly with increasing reaction temperature up to $140{ }^{\circ} \mathrm{C}$, and then increased slowly. This indicated that the optimum reaction temperature for the best grafting was about $180{ }^{\circ} \mathrm{C}$. The effect of reaction time on the grafting and crosslinking at a fixed reaction temperature $\left(180{ }^{\circ} \mathrm{C}\right)$ is shown in Figure 1(b). The grafting degree/efficiency and crosslinking degree increased with increasing up to about 15 min, and then leveled off. This indicated that the optimum reaction time for the best grafting was 15 min. From these results, it was found that the optimum temperature/time of melt reaction was $180{ }^{\circ} \mathrm{C} / 15 \mathrm{~min}$.

\section{Effect of initiator type on the on the grafting, crosslinking and melt flow index (MFI)}

Figure 2 shows the effect of the type of peroxide initiator on the \%grafting, grafting efficiency and gel content of CCA-g-EPDM. The \%grafting and grafting efficiency increased in the order of CCA-g-EPDM-T> CCA-g-EPDM-P > CCA-gEPDM-D. The CCA-g-EPDM obtained by using initiator T-101 had the highest \%grafting and grafting efficiency. Generally the nature of peroxide initiators is decisive for outcome in grafting and macromolecular degradation. To ensure a high yield of grafted product, it is advisable to use adequate peroxides, which have thermodynamic affinity with backbone polymer EPDM and the temperature range of decomposition of which corresponds to the
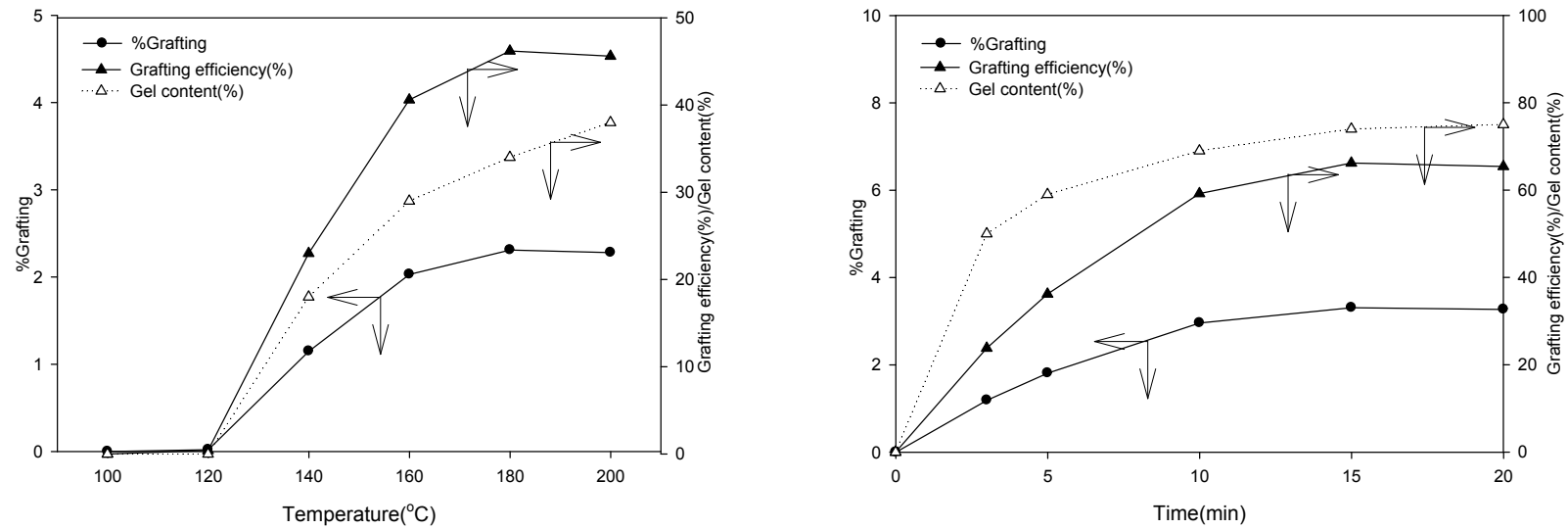

Figure 1. Effect of mixing temperature (a) and mixing time (b) on grafted CCA content and crosslinking degree of CCA-g-EPDM. (a) CCA content: $5 \mathrm{wt} \%$, initiator L-101 content: $0.05 \mathrm{wt} \%$ and mixing time: $15 \mathrm{~min}$. (b) CCA content: $5 \mathrm{wt} \%$, initiator L-101 content: $0.05 \mathrm{wt} \%$ and mixing temperature: $180{ }^{\circ} \mathrm{C}$. 




Figure 2. Effect of initiator type on grafting degree (\%), grafting efficiency (\%) and gel content( $\%)$

thermal regime of reactive extrusion. The initiator 2,5-dimethyl-2,5-di(tert-butyl peroxy)hexane (T-101) appeared to meet for the most these requirements for melt grafting of citraconic acid onto EPDM. Therefore, we used 2, 5-dimethyl-2, 5-di (tert-butyl peroxy)hexane (T-101) as an initiator in this study.

The effect of the type of initiator on the melt flow index is shown Table 1. The melt flow index (MFI), the mass rates (g/10min) of flow of polymer through a specified capillary under controlled conditions(temperature: $190{ }^{\circ} \mathrm{C}$, the nominal load: 2.16 $\mathrm{kg}$ ) of pristine EPDM and as-polymerized EPDM-g-CCA samples were measured to investigate the extent of reaction of EPDM with CCA during melt mixing. Generally, the MFI of polymer is directly related with melt viscosity which depended on molecular weight (MW) and MW distribution and structure (branching/ crosslinking, polar/nonpolar). Additionally, in case of practical application, MFI is a critical factor deciding the melt processibility and the usability requirements of the customers of polymers. The MFI of CCA-g-EPDM with different initiators increased in the order of CCA-g-EPDM-D> CCA-g-EPDM-P> CCA-g-EPDM-T. The increasing trend of MFI is reverse of that of grafting efficiency. The CCA-g-EPDM obtained by using T-101 had the lowest value of MFI. The lowest MFI of T-101 should be attributable to the highest grafting/crosslinking reactions. Therefore, the initiator T-101 was used to investigate the effect of dosages of monomer and initiator on the grafting and crosslinking described later.



Figure 3. FTIR spectra of pristine EPDM, CCA and CCA-g-EPDM. CCA: $5 \mathrm{wt} \%$, L-101: $0.05 \mathrm{wt} \%$ and grafted CCA content: $4.15 \mathrm{wt} \%$.

\section{Characterization of CCA-grafted-EPDM}

The FTIR spectra of pristine EPDM, CCA and grafted EPDM (CCA-g-EPDM, grafted CCA content: $2.31 \%$ ) are shown in Figure 3. Pristine EPDM shows the characteristic bands of the asymmetric deformation of the methyl group at $1463 \mathrm{~cm}^{-1}$, the methyl group of the diene group $\left(\mathrm{CH}_{3}-\mathrm{C}=\mathrm{C}\right)$ at $1436 \mathrm{~cm}^{-1}$ and the symmetric deformation band of methyl group at $1377 \mathrm{~cm}^{-1}$. CCA shows the characteristic band of the $\mathrm{C}=\mathrm{O}$ stretch peak at 1704 $\mathrm{cm}^{-1}$ and C-O stretch peak at $1270 \mathrm{~cm}^{-1}$ and $1180 \mathrm{~cm}^{-1}$ of carboxylic acid group of CCA component. By comparative analysis of spectra pristine EPDM, CCA and grafted EPDM, CCA-g-EPDM sample had both two characteristic peaks of pristine EPDM and $\mathrm{CCA}$, indicating the presence of CCA component in EPDM.

Effect of initiator/monomer dosage on the grafting degree (wt\%) and grafting efficiency/crosslinking degree (wt\%)

The effect of initiator [(2,5-dimethyl-2,5-di(tert-butyl peroxy)hexane (T-101)] dosage on the grafting degree (wt\%) and grafting efficiency/crosslinking degree (wt \%) is shown in Figure 4. The grafting degree (\%) increased markedly with increasing initiator dosage up to about $0.05 \mathrm{wt} \%$, and then decreased a little. The grafting efficiency ( $\mathrm{wt} \%)$ increased with increasing up to near $0.05 \mathrm{wt} \%$, and then decreased a little. The crosslinking degree (gel content, wt $\%$ ) increased sharply with increasing initiator dosage up to around $0.02 \mathrm{wt} \%$, and then increased very slowly. From these results, it was found that the optimum dosage of initiator T-101 was about $0.05 \mathrm{wt} \%$ for the best grafting and relatively low crosslinking. 


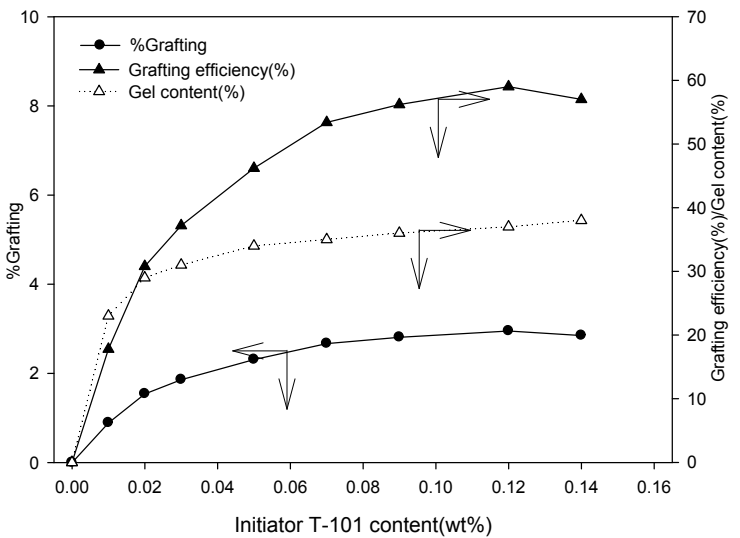

Figure 4. Effect of initiator L-101 content on grafting degree $(w t \%)$ and crosslinking degree (wt $\%)$ of CCA-g-EPDM. CCA content: $5 \mathrm{wt} \%$, mixing temp.: $180^{\circ} \mathrm{C}$ and time: $15 \mathrm{~min}$.



Figure 5. Effect of CCA concentration on grafting degree (wt $\%$ ) and crosslinking degree $(\mathrm{wt} \%)$ and crosslinking degree of CCA-g-EPDM. L-101 content: $0.05 \mathrm{wt} \%$, mixing temp.: $180^{\circ} \mathrm{C}$ and time: $15 \mathrm{~min}$.

Figure 5 shows the effect of monomer CCA dosage on the grafting degree (wt\%) and grafting efficiency /crosslinking degree (wt $\%$ ). The grafting degree increased markedly with increasing monomer CCA concentration increased, and then leveled off or decreased a little. However, the grafting efficiency decreased linearly with increasing monomer concentration. The crosslinking degree (wt $\%$ ) increased sharply in the initial stage of reaction, and then increased slowly. From these results, it was found that the optimum dosage of monomer CCA was about $5 \mathrm{wt} \%$ for the higher grafting and relatively low crosslinking.

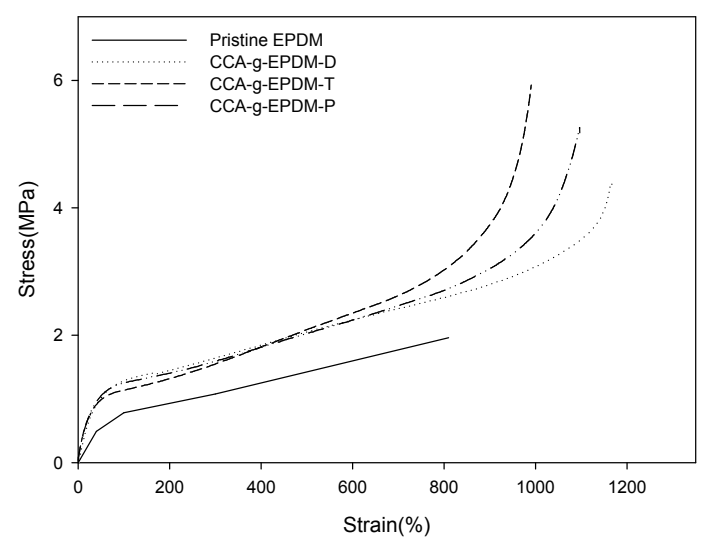

Figure 6. Stress-strain curves of CCA-g-EPDM samples using various initiators.

\section{Mechanical properties}

Figure 6 shows the stress-strain curves of CCA-g-EPEM film samples. The tensile strength, elongation at break and tear strength of film samples are shown in Table 1. The tensile strength, elongation at break and modulus at $100 \%$ and $300 \%$ of CCA-g-EPEM samples were higher than those of pristine EPDM (see Table 1). This indicates marked increases in the tensile strength and modulus at $100 \%$ and $300 \%$ as a result of grafting. Tensile strength of CCA-g-EPDM samples increased in the order of CCA-g-EPDM-T> CCA-g-EPDM-P > CCA-g-EPDM-D. However, the elongation at break increased in the order of CCA-g-EPDM-D $>$ CCA-g-EPDM-P > CCA-g-EPDM-T. The tear strength of CCA-g-EPEM samples were higher than that of pristine EPDM. The shore A hardness increased in the order of CCA-g-EPDM-D $\fallingdotseq$ CCA-g-EPDM-P > CCA-g-EPDM-T > pristine EPDM. From these results tear strength and shore A hardness were also raised by grafting.

\section{Conclusions}

Citraconic acid (CCA) was grafted onto an ethylene-propylene-diene terpolymer (EPDM) using various peroxide initiators on a Haake Rheocorder. The influence of mixing condition and reactants (CCA/initiator) contents is very important to obtaining optimal grafting condition and content. In this context, this study focused on the effects of mixing (reaction) condition and monomer content/initiator type and content on the grafting degree, grafting efficiency and crosslinking degree(gel content), melt flow index and mechanical properties of EPDM-g-CCA. 
Three different organic peroxides [dicumyl peroxide (DCP), 2, 5-dimethyl-2, 5-di(tert-butyl peroxy)hexane (T-101), and di(tertbutyl peroxy-isopropyl)benzene (P-14)], which satisfactorily dissolve in EPDM, but do not dissolve in the monomer CCA, were used to find the optimum initiator. As the grafting degree/crosslinking degree increased, the tensile strength increased significantly, but elongation at break and melt flow index decreased. The initiator 2, 5-dimethyl-2, 5-di(tert-butyl peroxy)-hexane (T-101) was found to be the best for the highest grafting. The grafting degree increased markedly with increasing monomer CCA/initiator T-101 contents and mixing temperature/time, and then leveled off or decreased/increased a little. It was found that the optimum monomer $\mathrm{CCA} /$ initiator $\mathrm{T}-101$ contents and reaction temperature/time were about 5/0.05 wt $\%$ and $180{ }^{\circ} \mathrm{C} / 15 \mathrm{~min}$, respectively. The sample CCA-g-EPDM-T [(\% grafting: 2.31 , grafting efficiency (\%): 46, and gel content (\%): 34)] prepared under the optimal conditions in this study showed relatively high mechanical strength and low melt flow index, highlighting its promising applications in new synthetic rubbers.

\section{Acknowlegements}

This work was supported by Fundamental R\&D Program for Core Technology of Materials funded by the Ministry of
Knowledge Economy, Republic of Korea (Project Number 10037160).

\section{References}

1. Bhattacharya, A.; Misra, B.N. Prog. Polym. Sci. 29, 767 (2004).

2. Rzayev, Z.M.O. Int. Rev. Chem. Eng. 3, 153 (2011).

3. Fenouillot, F; Cassagnau, P; Bounor-Legare, V. Int. Polym. Processing, 3, 218 (2007).

4. Dimitrova, T. L; Colletti, C.; La Mantia, F, P. Bulg. J. Phys. 32, 204 (2005).

5. Dimitrova, T. L; La Mantia, F, P.; Pilati, A; Visco, A.M. Polymer, 41, 4817 (2000).

6. Olga, P. G; Jozsef, K.K. European Polymer Journal 36, 1419 (2000).

7. Pesetskin, S.S.; Jurkowski, B.; Krivoguz, Y.M.; Urbanowicz, R. J. Appl. Polym. Sci. 65, 1493 (1997).

8. Pesetskin, S.S.; Jurkowski, B.; Krivoguz, Y.M.; Olkhov, Y.A. J. Appl. Polym. Sci. 81, 3439 (2001).

9. Jurkowski, B.; Pesetskin, S.S.; Olkhov, Y.A.; Krivoguz, Y.M; Kelar, K. J. Appl. Polym. Sci. 71, 1771 (1999).

10. Pesetskin, S.S.; Jurkowski, B.;Makarenko, O.A. J. Appl. Polym. Sci. 86, 64 (2002). 